\title{
DEVELOPING A MODEL OF PARTNERSHIP MANAGEMENT BETWEEN THE VOCATIONAL HIGH SCHOOL AND THE EMPLOYMENT DOMAIN IN THE CURRICULUM OF INDUSTRIAL WORKING PRACTICE
}

\author{
Harbiyah Gani \\ Universitas Muhammadiyah Aceh \\ Husaini Usman \\ Universitas Negeri Yogyakarta
}

\begin{abstract}
The study was to develop a model of partnership management between the vocational high school (VHS) and the employment domain in the curriculum of industrial working practice under the activities of planning, implementation, monitoring, and evaluation in the vocational high schools of Banda Aceh. The study used the research and development method design with several phases that had been developed by Borg \& Gall. The data type in the study was qualitative and quantitative. For the qualitative data analysis, the researcher used the interactive analysis that had been developed by Milles \& Huberman. On the other hand, for the quantitative data analysis the researcher used a Likert-scale measure. The research subjects were vocational education practitioners and experts. The data gathering was conducted by means of documentation, observation, interview, and delphi techniques; all of the methods were implemented until the researcher found the conceptual model. Then, the researcher involved the experts in the model testing by using the Delphi technique resulting in a hypothetical model from the conceptual to be used as the basis for developing the final model. Eventually, the researcher drew the following conclusion: (1) The partnership between the VHS and the employment domain had been pursued by all of the vocational high schools in the City of Banda Aceh but there had not been any clear and integrated model of partnership management; and (2) the researcher generated a model development of partnership management between the VHS and the employment domain in the curriculum of industrial working practice clearly, practically, and effectively.
\end{abstract}

Keywords: partnership management, employment domain, vocational education

Permalink: http://dx.doi.org/10.21831/jpv.v8i3.22107

Contact Harbiyah Gani@ harbiah_gani@yahoo.com

Universitas Muhammadiyah Aceh, Jl. Muhammadiyah No.91, Batoh, Lueng Bata, Kota Banda Aceh, Aceh 23123, Indonesia 


\section{INTRODUCTION}

The present study is to develop a model of management partnership between the VHS and the employment domain under the activities of planning, implementation and evaluation toward the curriculum of working industrial practice. The research problems in the study are as follows: (1) which type of partnership management model is able to be implemented in the state vocational high schools of Banda Aceh City under the curriculum of industrial working practice and what are the constraints within the implementation?; (2) how is the model of partnership management between the VHS and the employment domain in the three state vocational high schools of Banda Aceh City?; and (3) what are the characteristics and the effectiveness of partnership management model between the VHS and the employment domain in the curriculum of industrial working practice? Then, the results of the study might be made as guidelines in establishing the partnership between the VHS and the employment domain and this will be the benefit of the study for the institutions, the researcher, and the domain. The specifications of the model are as follows: (1) possessing the types and the principles of partnership management; (2) possessing collaboration in the partnership phases theoretically (Epstein et al., 2009, p. 105), empirically (Suaidin, 2010), and formally (Direktorat Pembinaan Kursus dan Kelembagaan, 2010).

Linda \& Christopher (2007, p. 8) stated that although the students of the vocational high schools get the benefits of closed relationship between the industrial domains and the academicians, the university students and the curriculum development, the strategy for pursuing the industrial involvement in addition to the multiple educational institutions frequently is messy and lacks focus, commitment, and resources. The existing approach is still traditional and is frequently ruthless toward the industrial domains; as a result, it has not been sufficient anymore for the contemporary educational institutions to pursue the importance of society involvement and of curriculum relevance. This awareness encourages the necessity of pioneering a new strategic approach that has initiative toward the involvement of industrial domains based on the partnership approach.
The implementation of industrial working practice for the vocational high school students in the employment domain has been one of the partnership form which implementation still encounters many constraints. One of the constraints is the existence of different industrial working practice facilities; as a result, the industrial working practice becomes ineffective.

The philosophy of vocational education management refers to two of the 16 vocational education postulates that have been developed by Prosser \& Quigley (1950) namely: (1) the vocational education will be effective if the students are taught with similar materials, tools, machineries, and assignments because the students will work effectively and efficiently if they are provided with the learning environment that looks similar to their actual working environment such as the replica of the actual working environment where they will be working; and (2) the vocational experience will be effective if the assignments in the exercises have operational similarities to the tools and the machineries that they will use in their actual working environment.

In the Curriculum and Learning Affairs under the Government Regulation Number 19 Year 2005 Chapter 1 Article 1 Verse 13 (Presiden Republik Indonesia, 2005), it is mentioned that "Curriculum is a set of plan and arrangement toward the objectives, the contents and the materials that will be used as the guidelines of implementation in achieving certain educational objectives." Curriculum and learning have been important matters in the school because a curriculum serves as the guidelines for implementing the learning process as having been explained by (Arikunto \& Yuliana (2008, p. 131): "Learning curriculum refers to managerial activities that have been conducted together by emphasizing the efforts of improving the teaching-learning interaction". The objective of the curriculum and learning is to improve the curriculum and learning quality and, in order to achieve the objective, the schools should design and improve the strategies of curriculum and learning development continuously. Sukmadinata $(2005$, p. 6) mentions, "curriculum and learning are designed in order to achieve the educational objectives that provides clear educational guidelines, directions, content, and process." Similarly, the Department of National Education (Pusat Kuriku- 
lum Badan Penelitian dan Pengembangan, 2007 , p. 10) states, "The vocational high schools have speciality in the productive subjects." Similar to the other subjects, the content standards and the competence standards of the graduates for the productive subjects should be reviewed. The review activities might be performed by involving the teachers and the lecturers who have industrial experience and the professionals in terms of the related association. (Choate, Enright, Miller, Poteet, \& Rakes (1992, p. 2) mentions that the curriculum and learning that will be developed might refer to several governing curricula and learning forms and one of these forms is the competency-based curriculum in which all of the curriculum and learning activities are directed to the functions and the capabilities that have been demanded by the employment market or the employment domain.

\section{RESEARCH METHOD}

The study used the Research and Development (R\&D) method. Previously, the study of research and development was to find a model of partnership between the VHSs and the employment domain in the curriculum of industrial working practice. However, during the initial survey the researcher found that the management of partnership between the VHSs and the employment domain had been running well but there had not been a good and overall model of partnership. Therefore, the objective of the study is to develop a model of management toward the partnership between the VHS and the employment domain in the curriculum of industrial working practice.

The research and development model design refers to the guidelines of 10 steps in performing an R \& D study proposed by Borg \& Gall (1983, p. 775) as follows: “(1) research and information collecting, (2) planning, (3) developing preliminary form of product, (4) preliminary field testing, (5) main product revision, (6) main field testing, (7) operational product revision, (8) operational field testing, (9) final product revision, and (10) dissemination and implementation."

The developmental procedure of the management model follows the steps proposed by Borg \& Gall above. Although the researcher did not fully attend the overall 10 steps, the model development was still possible to be conducted. The study was conducted in 2012 (the initial survey) until 2014 (the model testing) to several vocational high schools in the City of Banda Aceh, the Province of Nanggroe Aceh Darussalam. The subjects of the research consisted of experts and technological and vocational education practitioners. Data gathering techniques consisted of initial survey, documentation study, interview, and Delphi technique. There were two kinds of research data namely: (1) qualitative data; and (2) quantitative data. For the qualitative data analysis, the researcher used the interactive analysis proposed by (Miles \& Huberman, 1994, pp. 2325) with the following steps: (1) data gathering; (2) data reducing and presenting; and (3) conclusion drawing. Meanwhile, for the quantitative analysis the researcher used the Likertscale analysis toward the data resulting from the field product testing questionnaire. The field product testing questionnaire contained several questions/statements for gathering the data. The quantitative data were gathered in order to measure the level of product feasibility that had been attained from the product users. The data then were analyzed by means of Likert scale in order to find the lowest score, the highest score, and the average score.

\section{RESEARCH RESULTS AND DISCUSSION}

The management of partnership in the curriculum and learning affairs and in the activities of planning, the implementing and the evaluating for the curriculum and learning affairs showed that: (1) within the domain of organizational structure the employment domain had not been included in the curriculum domain; however the employment domain had been included in the organizational structure of the vocational high schools; and (2) from all of the tasks and the authority that had been under the domain of curriculum department, there had not been any single task showing written agreement with the employment domain although verbally the school members had admitted the involvement of the employment domain in designing the curriculum affairs; (3) it was admitted that the curriculum that had been developed in the schools was totally different from that of the working system in the employment domain; (4) in the curriculum structure, the internship programs had not been included and there were industrial working 
practice programs; and (5) the activities in the curriculum department in general were still internal within the schools and there had not been any special curriculum that had been designed for developing the curriculum and learning in the detailed implementation of the working industrial practice.

\section{The Initial Product Development Planning.}

After analyzing the results of the study in the three state vocational high schools of Banda Aceh City, namely Negeri 1 State Vocational High School, Negeri 2 State Vocational High School and Negeri 3 State Vocational High School, the researcher found similar situations that had been explained in the previous paragraphs regarding the topic of management model for the partnership between the vocational high schools and the employment domain, the constraints that the vocational high schools encounter in their partnership with the employment domain, and the evaluation toward the curriculum affairs.

The discussion was conducted with the vocational education experts, the vocational education practitioners, several students of Postgraduate Programs, Technology and Vocation Study Program, Yogyakarta State University and the sponsor. After the discussion, the researcher found a conceptual management model toward the partnership between the vocational high schools and the employment domain in the curriculum of industrial working practice. The conceptual model was viewed from three managerial functions in terms of curriculum and learning process namely: (1) plan-ning; (2) implementing; and (3) evaluating. The results of the discussion were turned into a conceptual chart that was called the conceptual management model of partnership between the vocational high schools and the employment domain in the curriculum of industrial working practice. From the research and development efforts in the systematic, complicated, and time-consuming curriculum of industrial working practice, the researcher found multiple research instruments that might be used for developing the partnership management.
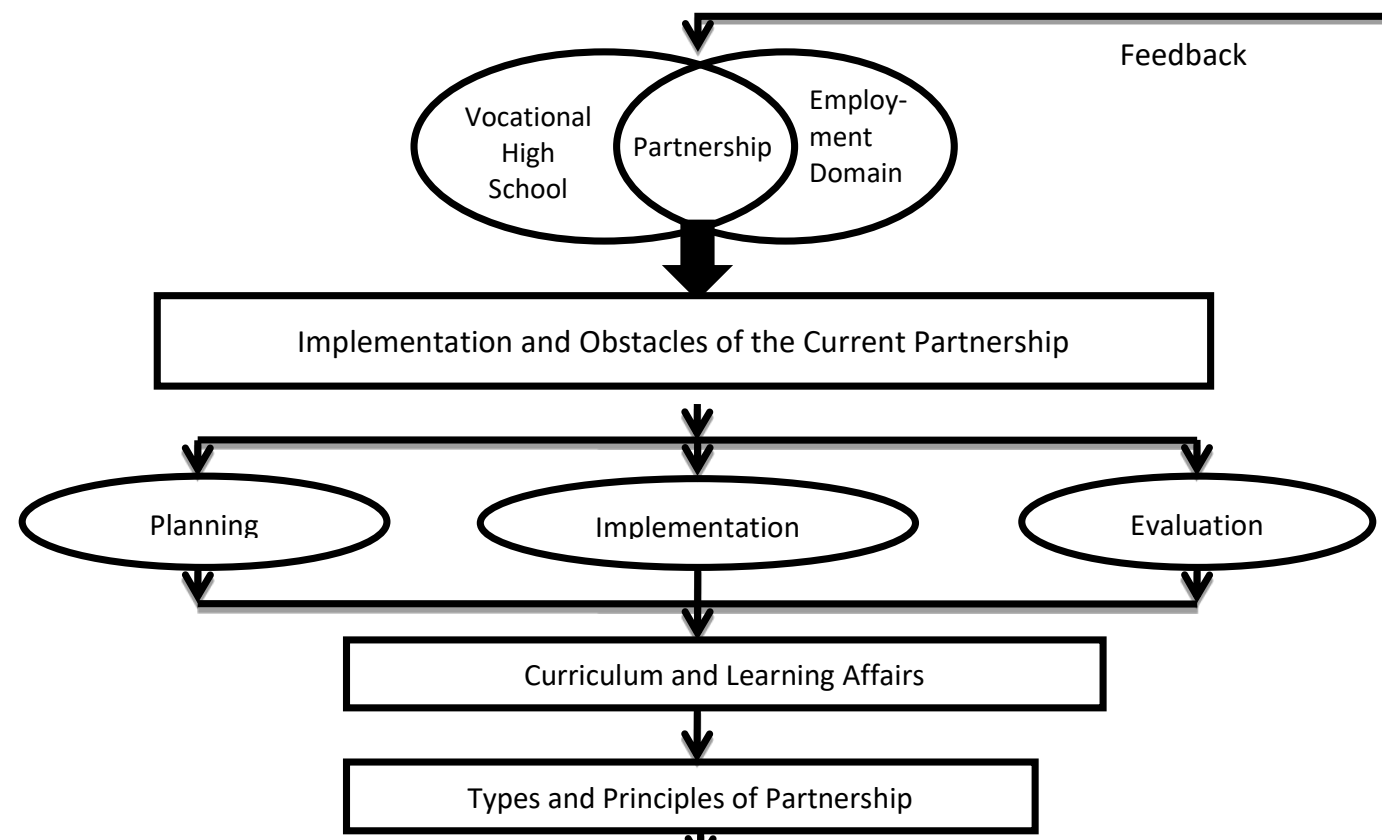

Partnership Steps for Vocational High Schools with the Employment Domain: Theoretical; Empirical; Juridical

\section{$\boldsymbol{\varphi}$}

Vocational High School Partnership Management Model with the Employment Domain in the Industrial Work Practice Curriculum

Figure 1. The Conceptual Management Model for the Partnership between the Vocational High Schools and the Employment Domain 

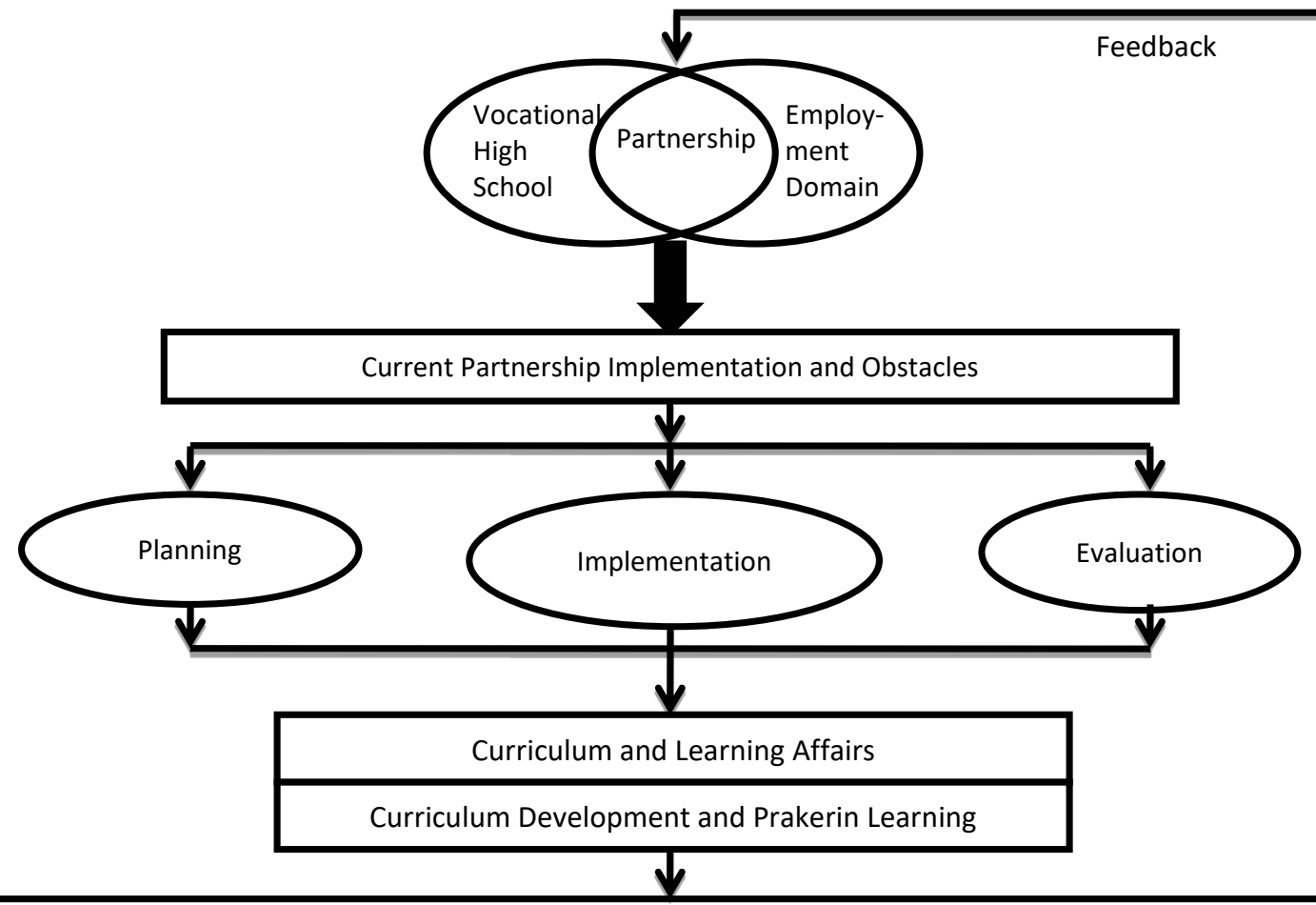

Types of Partnership Models: (1) Psuedo Partnerships, (2) Mutualism Partnerships, (3) Conjugation Partnerships. And 3 Partnership Principles: (1) Linear Union of Partnership (LUoP); (2) Subcoordinate Union of Partnership (SUoP); (3) Linear Collabotive Union of Partnership (LCUoP).

Theoretical Partnership Steps (Epstein, 2010), Empirical (Suaidin, 2010) and Juridical (Direktorat Pembinaan Kursus dan Kelembagaan, 2010)

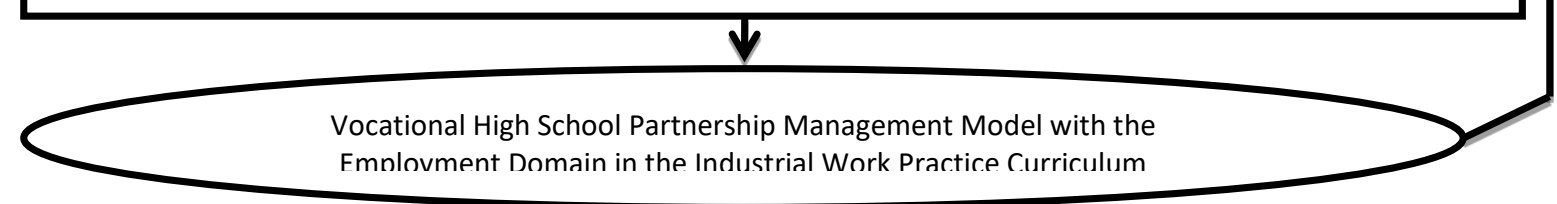

Figure 2. The Hypothetical Management Model for the Partnership between the Vocational High Schools and the Employment Domain

The conceptual framework of the partnership management model had been a summary of research instruments that contained the questions toward the description of components and indicators for the management model development in the curriculum and learning affairs. Based on the results of the continual consultation/discussion with the sponsor and the co-sponsor, the researcher designed an initial product that was called as the hypothetic management model for the partnership. The conceptual management model can be seen in Figure 1.

Based on the results of continual consultation/discussion with the sponsor, the researcher designed an initial product called the hypo- thetical partnership management model. This hypothetical model can be seen in Figure 2.

The hypothetical model testing was limited to the vocational education practitioners. The results of the hypothetical model testing were reviewed. The results of the revision were tested by the vocational education experts by means of the Delphi technique with two rounds. The first round of of Delphi technique consisted of three managerial components namely: (1) planning; (2) implementing; and (3) evaluating. The three components in the model were equipped with development indicators for the curriculum of industrial working practice. The results of the experts' testing can be seen in Figure 3. 

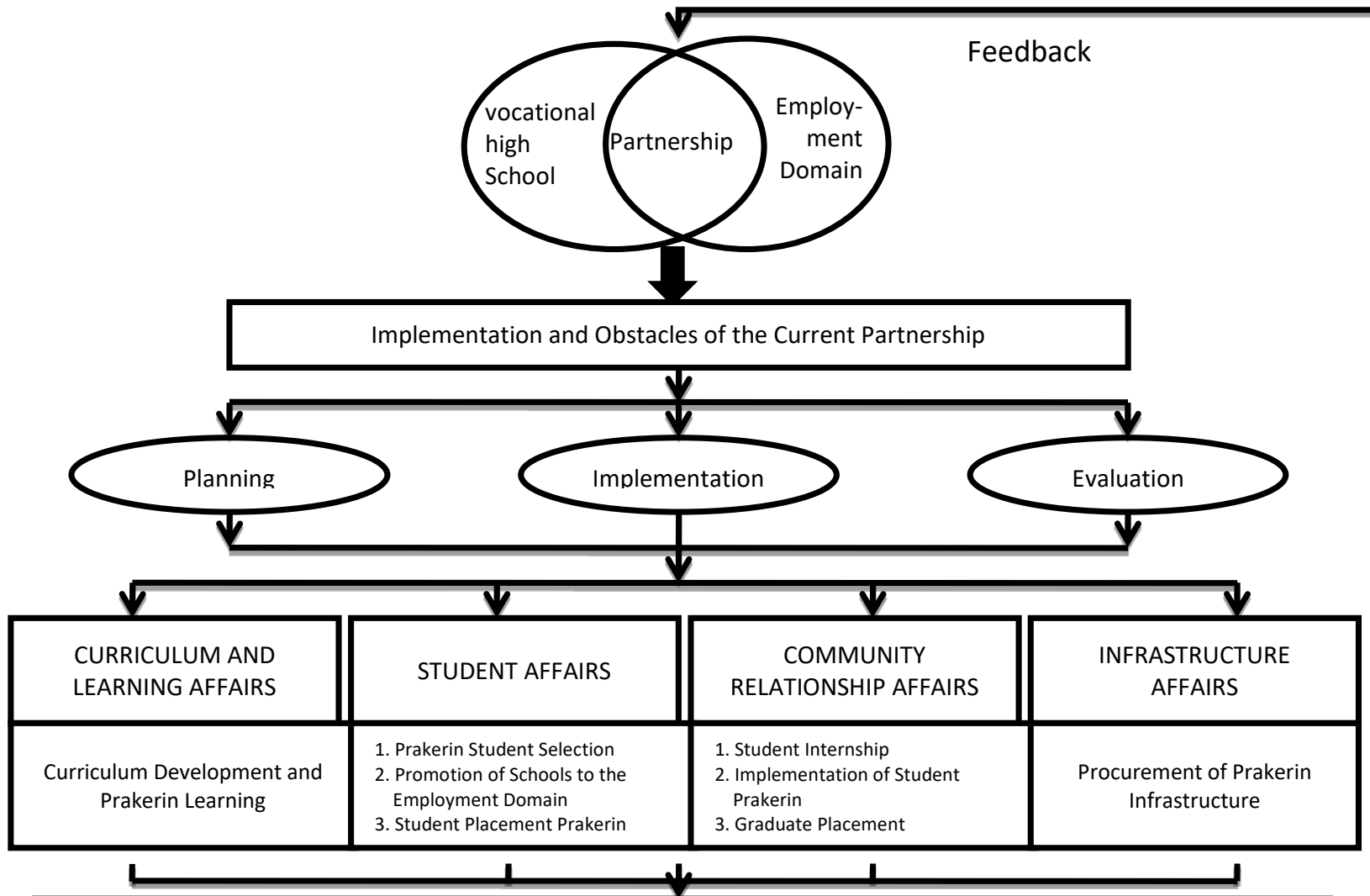

Types of Partnerships: (1) Psuedo Partnerships, (2) Mutualism Partnerships, (3) Conjugation Partnerships. And 3 Partnership Principles: (1) Linear Union of Partnership (LUoP); (2) Subcoordinate Union of Partnership (SUoP); (3) Linear Collabotive Union of Partnership (LCUoP)

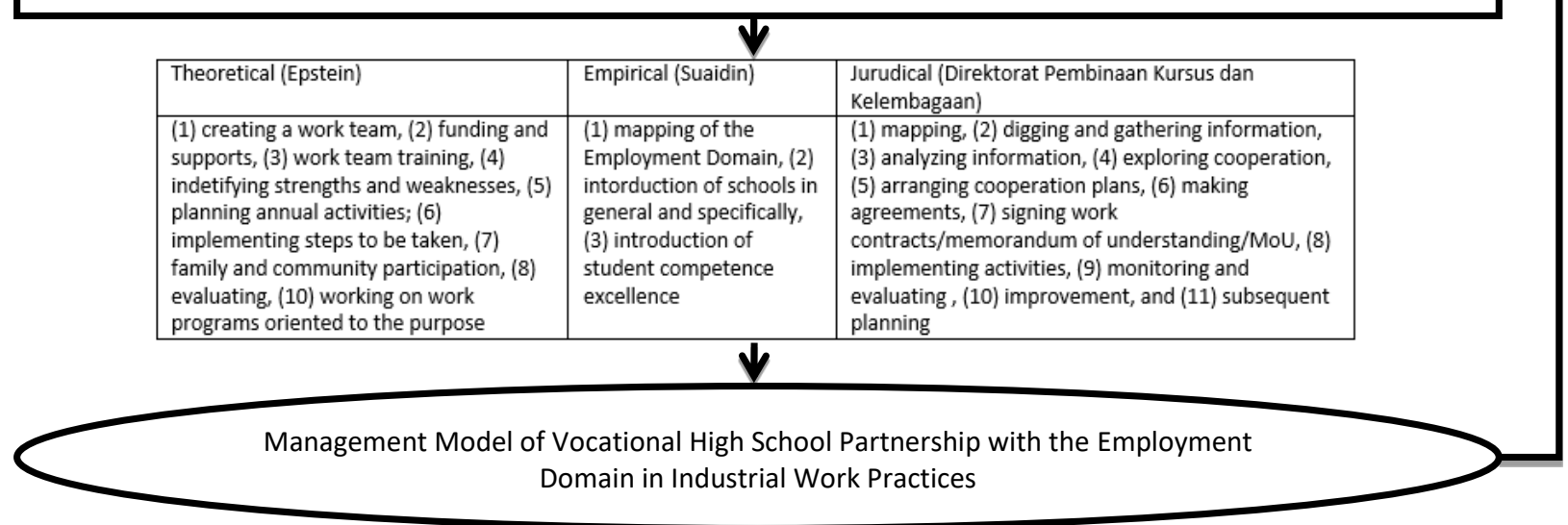

Figure 3. The Management Model of Partnership Between the Vocational High Schools and the Employment Domain Resulting from the First Round of Delphi Techniques Implementation

The results of experts' testing of the first round of the Delphi techniques were not satisfying because there were several experts whose scores were not synchronized. The Delphi was then conducted in the second round. The results of the testing in the second round, together with the feedbacks from the expert judgement, showed that the three managerial components, namely planning, implementing, and evaluat- ing, in the proposed case, namely the curriculum and learning affairs, should be maintained. Then, the three indicators for the curriculum of the industrial working practice were: (1) developing the industrial working practice curriculum and learning; (2) synchronizing the industrial working practice curriculum and the employment domain; and (3) involving directly the employment domain in developing the 
industrial working practice curriculum. The experts also suggested that the researcher should add two more indicators of: (1) performing supervision; and (2) performing control. The end result was that there was a total of six indicators for the development.

The partnership type that the experts proposed was the mutualistic partnership because this type had been considered more apropriate to the expected conditions of vocational high schools recently. For the partnership principle, the experts suggested the linier collaborative union of partnership (LCUoP) that was thought to be more appropriate for the managerial function of the industrial working practice in the employment domain. Regarding the partnership phases that had been proposed theoretically, empirically and formally, all of the experts stated that all of the phases should be collaborated by using the phases that had been considered important in establishing a partnership. As a result, the researcher attained the following phases of establishing a partnership: (1) assembling a working group of industrial working practice; (2) providing training programs for the working group; (3) mapping the school and the employment domain; (4) analyzing the job needs that should be put into the partnership within the industrial working practice in terms of cost, time, and location; (5) designing a memorandum of understanding (MoU); (6) establishing partnership in the industrial working practice; (7) performing monitoring and evaluation toward the partnership in the industrial working practice; and (8) composing reports of partnership establishment. The results of the expert testing by means of the Delphi techniques in the second round were analyzed and put into the model of management for the partnership between the vocational high schools and the employment domain. The partnership management is illusrated in Figure 4.

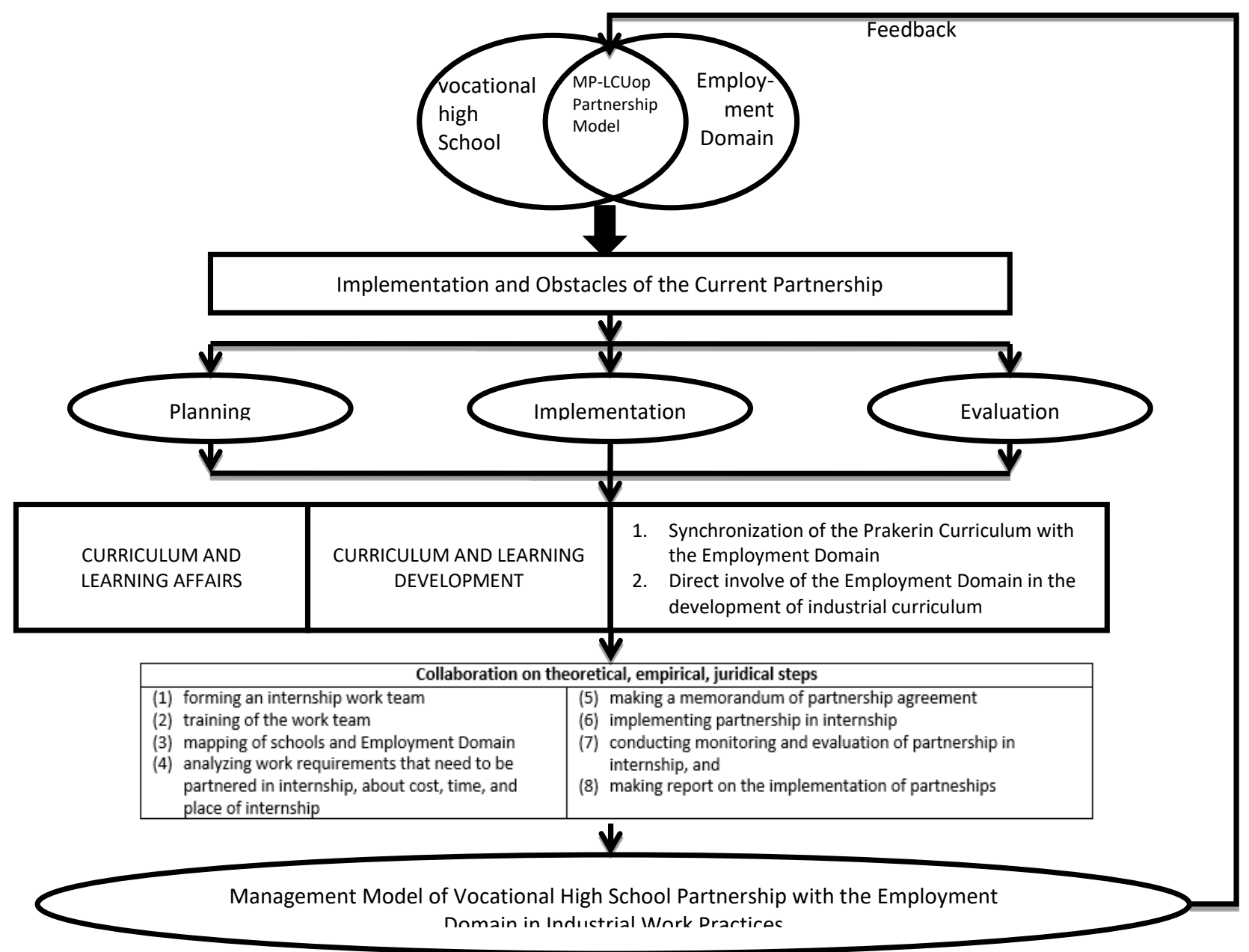

Figure 4. The Management Model of Partnership between the Vocational High School and the Employment Domain Resulting from the Second Round of Delphi Techniques 
The results of Delphi techniques in the second round were were also continually consulted to the sponsor. Based on the analysis and the continual consultation, the researcher designed the final partnership management model. The product model was elaborated in the development guidelines of the model in four phases: (1) planning; (2) implementing; (3) monitoring; and (4) evaluation. The four phases were conducted in the curriculum and learning affairs of the industrial working practice. The product of the field testing of the management model was intended to attain feedbacks and suggestions through the level of component importance and model indicator percentage. After the model had received more feedbacks and further revisions, the researcher improved the model until the model was accepted by the institutions of technological and vocational education in the City of Banda Aceh and the nearby regions. The final model referred to the management of partnership between the vocational high schools and the employment domain in terms of curriculum affairs of industrial working practice. The final model was then put into the field testing in all of the technological and vocational institutions. After the field testing had been done, the researcher, together with the sponsor, revised the model further into the guidelines of the management model. The final management model for the partnership between the vocational high schools and the employment domain in the curriculum of industrial working practice is shown in Figure 5.

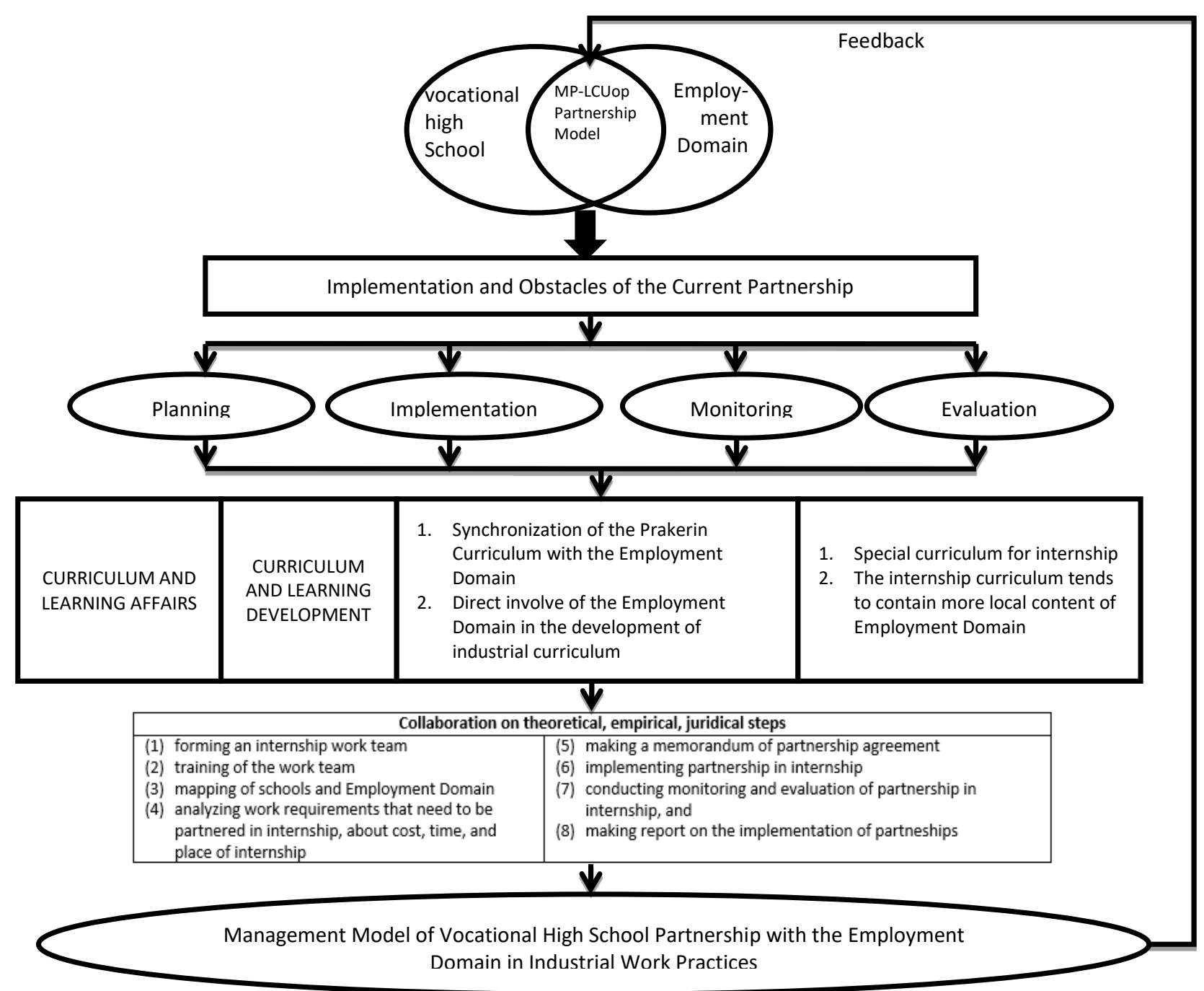

Figure 5. The Final Management Model for the Partnership Between the Vocational High Schools and the Employment Domain in the Curriculum of Industrial Working Practice 


\section{Preliminary Experiment and the Revision}

Borg \& Gall (1983, pp. 771-794) stated that the first experiment would be called as the preliminary experiment and within the preliminary experiment of the study the researcher would like to test the development feasibility of the management model for the partnership between the vocational high schools and the employment domain. In this case, the test was performed with the asistance of practitioners and academicians. The preliminary experiment was conducted by distributing the product of the partnership development with four managerial functions: (1) planning, (2) implementing, (3)monitoring, and (4) evaluating, directed to the curriculum affairs in the industrial working practice. The preliminary experiment involved several subjects: vocational education experts, vocational education practitioners (such as vocational high school principals and vocational high school vice principals), and the employment domain. The main objective of the the preliminary experiment was to attain feedbacks regarding the substance in the instruments of the partnership model with the four managerial phases of (1) planning, (2) implementing, (3) monitoring, and (4) evaluating. The substance of the instrument included the curriculum affairs of industrial working practice, starting from the background of the research, the language that had been used, the content clarity, the number of question items to the feedback sheet. The instrument consisted of 4 components with 6 indicators. Based on the comments and suggestions from the respondents, both in the draft and in the feedback sheet, the researcher found that the guideline concepts needed to be revised as a preliminary product revision. The results of the preliminary revision was used as the basis for the next experiment.

One of the characteristics in the management model was that the model had been simple in terms of implementation with quite complete information. As a result, the management model had been one of the alternatives that might be used by the vocational high schools for establishing partnership with the employment domain in the curriculum of industrial working practice. The model had been tested qualitatively and the results showed that the management model was regarded as practical, objective, and efficient.
The management model for the partnership between the vocational high schools and the employment domain in the curriculum of industrial working practice was supported by the model guidelines that had been quite brief, clear, and complete. Therefore, the management model was easy to be implemented by the vocational high school practitioners in the field especially as guidelines in establishing partnership with the employment domain in terms of designing the industrial working practice curriculum. The reason was the management model had characteristics that were similar to those of the vocational high schools. The developed model was different from other models in the following aspects: (1) the direct involvement of the curriculum department in establishing the partnership with the employment domain in the curriculum of industrial working practice; (2) the efforts that should be done by the curriculum department in establishing the partnership with the employment domain in terms of the activities of industrial working practice curriculum; (3) the importance of the curriculum department involvement in the monitoring toward the partnership between the vocational high schools and the employment domain in terms of the industrial working curriculum; and (4) the role of the curriculum department in the evaluation of the partnership between the vocational high schools and the employment domain in terms of the industrial working practice curriculum.

\section{Product Strengths}

The strengths of the management model for the partnership between the vocational high schools and the employment domain in the curriculum of industrial working practice were seen as follows. (1) The partnership management model had been developed based on the results of documentation study and initial survey toward several vocational high schools and the surrounding industries. The initial survey was conducted in order to ensure the partnership between the vocational high schools and the employment domain. (2) The constraints in the implementation of partnership between the vocational high schools and the employment domain had been a very important benchmark for developing the partnership management model that would offer solutions for overcoming those constraints. (3) In addi- 
tion to having been based on the strong partnership theory and equipped with partnership objectives and partnership benefits, the partnership management model had also been equipped with the implementation models and the partnership principles developed by the partnership experts. (4) The collaboration of theoretical, empirical, and formal partnership phases in the development guidelines of the partnership management model had increased the ease of implementing the model guidelines for the partnership between the vocational high schools and the employment domain. (5) There had been positive responses from the employment domain toward the management model for the partnership between the vocational high schools and the employment domain due to the ease in implementing the partnership with the vocational high schools in terms of industrial working practice curriculum. (6) There had been great involvement from all of the school members under the department of curriculum in the industrial working practice and in the management mode for the partnership between the vocational high schools and the employment domain in the industrial working practice curriculum. The great involvement made the level of responsibility in the partnership between the vocational high schools and the employment domain improve because the four managerial phases in the model were similar among the vocational high school students.

\section{Product Weaknesses}

The management model for the partnership between the vocational high schools and the employment domain in the curriculum of industrial working practice had several weaknesses that can be seen as follows. (1) The validation of the partnership management model had not been disseminated due to the limited time. Dissemination was only provided to the experts and the practitioners. As a result, most of the vocational high school authorities had not been familiar with the characteristics and the implementation of management mode in the model. (2) The partnership planning was less difficult to be designed; however, the partnership implementation, monitoring, and evaluation heavily demanded certain skills. As a result, continuous training programs were needed for the teachers and instructors. The reason was that sending vocational high school supervising teachers to the employment do- main and instructors to the vocational high schools was merely a visitation and was not a direct involvement in the industrial working practice. (3) The absence of a working team in the partnership was a big constraint for the implementation of management model because without a solid working team the partnership would be less directed and less responsible. (4) There had been so many managerial activities in implementing the development of the partnership management model. These covered planning, implementing, monitoring, and evaluating activities toward the school affairs in the curriculum of industrial working practice. Therefore, the schools also needed a huge amount of fund.

\section{CONCLUSION}

From the results of the research and development study, the following items of conclusion can be drawn. First, the partnership management model has been implemented by all of the vocational high schools in the City of Banda Aceh. However, the implementation of the model has not been in accordance with the theories and phases of a clear, integrated model. The recent partnership indeed has been more focused on the implementation of the students' industrial working practices in the employment domain. Unfortunately, the partnership has not totally subjected to the managerial activities of planning, implementation, monitoring and evaluation especially in the curriculum affairs of industrial working practice.

Second, the constraints that have been encountered in the partnership management model can be delineated as follows: (a) there has been lack of planning for the management model for the partnership between the vocational high schools and the employment domain; (b) most of the implementation of the partnership management model has been under the initiative of the vocational high school rather than the employment domain; (c) monitoring toward the implementation of the partnership management model relies more on the evaluating activities; and (d) most of the evaluating activities of the partnership management model have been focused only on the psychomotoric aspects.

Third, the development of the model is still limited to the curriculum development for 
the productive subjects only. Actually, the important components and indicators in partnership within the curriculum and learning affairs are as follows: (a) having curriculum and learning development; (b) having synchronization between the curriculum and learning for the industrial working practice and the curriculum and learning for the employment domain; (c) having direct involvement of the employment domain in the industrial working practice development; (d) having industrial working practice-specified curriculum and learning; and (e) having employment domain local content-curriculum and learning for the industrial working practice.

Fourth, the apparent product characteristics of the partnership management model refers to the involvement of the four managerial phases of planning, implementation, monitoring, and the evalua-tion. It has been found that the model that has been developed by means of planning, implementation, monitoring, and evaluation has been regarded as effective.

\section{REFERENCES}

Arikunto, S., \& Yuliana, L. (2008). Manajemen pendidikan. Yogyakarta: Aditya Media.

Borg, W. R., \& Gall, M. D. (1983). Educational research: An introduction (4th ed.). New York: Longman Publishing.

Choate, J. S., Enright, B. E., Miller, L. J., Poteet, J. A., \& Rakes, T. A. (1992). Curriculum-based assessment and programming. Allyn \& Bacon.

Direktorat Pembinaan Kursus dan Kelembagaan. (2010). Modul 5. Membangun jejaring kerja (kemitraan). Jakarta: Direktorat Pembinaan Kursus dan Kelembagaan, Direktorat Jenderal
Pendidikan Nonformal dan Informal, Kementerian Pendidikan Nasional.

Epstein, J. L., Sanders, M. G., Sheldon, S. B., Simon, B. S., Salinas, K. C., Jansorn, N. R., ... Williams, K. J. (2009). School, family, and community partnerships; your handbook for action (3rd ed.). California: SAGE Publishing Company.

Linda, C., \& Christopher, W. (2007). Vocational education international approaches, developments and systems. New York: Routledge.

Miles, M. B., \& Huberman, A. M. (1994). Qualitative data analysis: an expanded source book. Thousand Oaks: Sage Publications, Inc.

Presiden Republik Indonesia. Peraturan Pemerintah Republik Indonesia Nomor 19 Tahun 2005 tentang Standar Nasional Pendidikan (2005).

Prosser, C. A., \& Quigley, T. H. (1950). Vocational education in a democracy. Chicago: American Technical Society.

Pusat Kurikulum Badan Penelitian dan Pengembangan. (2007). Naskah akademik kajian kebijakan kurikulum SMK. Jakarta: Pusat Kurikulum Badan Penelitian dan Pengembangan Departemen Pendidikan Nasional.

Suaidin. (2010). Pengembangan kerja sama kemitraan satuan pendidikan. Retrieved February 3, 2012, from http://suaidinmath.wordpress.com/ 2011/05/05/juknispengembangankerjasamadan-kemitraan-satuanpendidikan/

Sukmadinata, N. S. (2005). Landasan psikologi proses pendidikan. Bandung: Remaja Rosda Karya. 